\title{
DISTRIBUSI PENYAKIT Infectious Myo Necrosis Virus (IMNV) PADA UDANG VANNAMEI (Litopenaeus vannamei) DI PANTAI UTARA JAWA TIMUR
}

\section{DISTRIBUTION OF Infectious Myo Necrosis Virus (IMNV) IN WHITE SHRIMP VANNAMEI (Litopenaeus vannamei) IN NORTH COAST, EAST JAVA}

\author{
Andre Rekasana, Laksmi Sulmartiwi dan Soedarno \\ Fakultas Perikanan dan Kelautan Universitas Airlangga \\ Kampus C Mulyorejo - Surabaya, 60115 Telp. 031-5911451
}

\begin{abstract}
White shrimp vannamei (Litopenaeus vannamei) is the main commodities among shrimp farmers because it has a rapid growth, can be cultivated with high density and world market demand is large enough . Since being introduced in Indonesia, vannamei shrimp has spread to the north of East Java pesisisr like Probolinggo, Pasuruan, Lamongan and Tuban. Shrimp growth factors are must be faced on vannamei shrimp culture, including the problems of disease. One type of virus disease is an Infectious Myo Necrosis Virus (IMNV). IMNV has affecting to the 70\% of shrimp mortality (Tang et al., 2008).

This study aims to determine the distribution of IMNV on white shrimp vannamei from the northern coast of East Java. This research uses descriptive method by taking samples from five different location which 75 samples totaly. In this research also take the water quality parameter including $\mathrm{pH}$, DO, salinity and temperature. Whole of the samples performed the PCR test to determine how many samples which is indicating of IMNV.

Based on measurements of water quality at five different locations, the plots I, II and III obtained the temperature range between 29.3-30.2 ${ }^{\circ} \mathrm{C}$, salinity 90-30 ppt, $\mathrm{pH}$ 7.5-7.9, and DO 3.8-5.7 ppm. Temperature, $\mathrm{pH}$ and DO parameters show normally on white shrimp vannamei, while salinity shows different valve from normal conditions. Abnormallity happened in Situbondo with the salinity betwen 32-33 ppt and Pasuruan betwen 9-10 ppt.

Results showed that the number of the lowest infection is Lamongan (53\%) following Probolinggo (60\%), Tuban (67\%), Pasuruan (73\%) and the highest is from Situbondo (100\%)
\end{abstract}

Keywords : Litopenaeus vannamei, Infectious Myo Necrosis Virus (IMNV), water quality

\section{Pendahuluan}

Udang vannamei (Litopenaeus vannamei) merupakan komoditas baru dengan kualitas ekspor yang sangat menjanjikan. Udang vannamei memiliki keunggulan yaitu pertumbuhan yang cepat, dapat dibudidayakan dengan kepadatan tinggi mencapai 92-100 ekor $/ \mathrm{m}^{2}$ (Ruswahono, 2011). Udang vannamei memiliki ketahanan tubuh yang kuat, diantaranya adalah rentang salinitas yang sangat luas yaitu antara 15-30 ppt, sehingga masyarakat di daerah pesisir tertarik untuk membudidayakan udang vannamei.

Setelah 2 tahun diintroduksi di Indonesia, udang vannamei telah menyebar hingga ke pesisisr utara Jawa Timur seperti Probolinggo, Pasuruan, Lamongan dan Tuban dengan kondisi lingkungan yang sesuai dengan pertumbuhan udang vannamei. Menurut Dirjen Perikanan dan Kelautan (2010) dewasa ini produksi udang di Indonesia terkendala oleh timbulnya wabah penyakit yang datang dari luar Indonesia bersamaan dengan udang atau ikan lain yang diimpor, salah satunya adalah Infectious Myo Necrosis Virus (IMNV).

IMNV pertama kali ditemukan di Brazil pada tahun 2002 dalam kolam budidaya Litopenaeus vannamei (Tang et al., 2005). Penyakit yang ditandai dengan nekrosis otot rangka, saluran pencernaan dan ekor ini dapat menyebabkan kematian massal hampir $70 \%$ dari total udang yang ditebar selama satu siklus (Tang et al., 2008). Gejala klinis penyakit ini pada awalnya adalah perubahan warna putih pada otot rangka dan berubah menjadi warna merah pada pangkal ekor atau ruas terakhir dari abdomen udang vannamei (Dirjen Perikanan dan Kelautan, 2010). Udang vannamei akan mati secara bertahap di dasar tambak dan dapat menyebar luas jika tidak ada pemantauan secara dini (Prajitno, 2008).

Di Indonesia IMNV diketahui sudah menyerang udang putih yang dibudidayakan di tambak di kecamatan Kapongan kabupaten Situbondo dengan tingkat prevalensi pada sekitar bulan mei tahun 2006 sebesar 11,11\% 
(Nuraini, 2007), meskipun pada saat dilakukan survey di Kabupaten Situbondo terdeteksi adanya IMNV dengan prevalensi sebesar 100 $\%$. Hal tersebut tidak menutup kemungkinan bahwa di daerah lain saat ini sudah terdeteksi IMNV. Hasil survey dan analisa sampel udang putih di Laboratorium Kesehatan Ikan dan Lingkungan Balai Budidaya Ikan Payau (BBAP) Situbondo dari tahun 2006 sampai pertengahan tahun 2007 menunjukkan bahwa IMNV sudah menyebar di daerah pertambakan Kabupaten Probolinggo, Banyuwangi dan Kalimantan Selatan (Nuraini, 2008). Budidaya udang vannamei di Indonesia makin berkembang, sehingga perlu dilakukan penelitian tentang distribusi IMNV pada udang vannamei di pantai utara Jawa Timur.

\section{Metodologi}

Tempat dan Waktu Pelaksanaan

Penelitian dilaksanakan di

Laboratorium Basah Unit Pelayanan Teknis Pengembangan Budidaya Air Payau (UPT PBAP) Bangil, Jawa Timur bulan Maret hingga Mei 2011.

Materi Penelitian

Bahan yang digunakan adalah udang vannamei yang berasal dari tambak tradisional dan intensif yang diduga terkena wabah IMNV di Lamongan, Tuban, Pasuruan, Probolinggo dan Situbondo Jawa Timur. Bahan untuk uji PCR antara lain RNA extraction solution, alkohol absolut, chloroform, isopropanol, RTPCR PreMix (buffer, dNTPs, primer IMNV).

Peralatan yang digunakan adalah sterofoam, freezer, plastik klip, gel ice, sarung tangan. Peralatan yang digunakan untuk uji PCR adalah sentrifuge, gunting, mikro pipet, tabung ependorf, vortex dan kit IQ 2000. Peralatan pengukur kualitas air berupa $\mathrm{pH}$ pen/ refraktometer, DO meter dan termometer.

Rancangan Penelitian

Data hasil penelitian disajikan secara deskriptif yaitu penyajian data dengan memaparkan data dalam bentuk penjelasan, angka dan gambar yang dideskriptifkan dan juga dapat secara grafis yaitu dalam bentuk ataupun grafik guna mendapatkan gambaran tentang data-data penelitian sehingga lebih mudah di baca dan di pahami (Dergibson dan Sugiarto, 2002).

Prosedur Penelitian

a. Pengambilan Sampel

Sampel didapat dari tambak udang yang diduga terkena wabah IMNV di daerah Lamongan, Tuban, Pasuruan, Probolinggo dan Situbondo lalu dilakukan sampling secara acak.
Pengambilan sampel disesuaikan dengan jumlah yang ada yaitu minimal 5-10 ekor apabila kondisi lapangan tidak memungkinkan (Supriadi, 2004 dalam BKI, 2009). Sampel pada penelitian ini adalah sebanyak 75 ekor udang vannamei berumur 45 hari dengan berat ratarata 7-8 gram, panjang $8-10 \mathrm{~cm}$. Pengambilan sampel pada tiap daerah dilakukan dengan memilih 3 petakan tambak yang diduga terinfeksi IMNV, kemudian diambil masingmasing 5 ekor pada tiap petakan tambak secara acak.

b. Pemeriksaan dengan PCR

Udang sampel yang dibawa dalam keadaan hidup atau hampir mati dan secepatnya dilakukan pemeriksaan virus maupun pengambilan organ yang di duga ada penyakit. Untuk memastikan adanya infeksi IMNV pada udang vannamei maka langkah awal dilakukan skrining dengan teknik PCR.

Skrining dilakukan dengan metode

Polymerase Chain Reaction (PCR) menggunakan alat kit IQ 2000 dan primer khusus IMNV. PCR merupakan teknik amplifikasi DNA/RNA tertentu secara sistematis yang dilakukan secara in vitro. Metode ini telah diterapkan secara luas baik pada crustacea maupun pada ikan, karena tingkat akurasinya yang cukup tinggi dan cepat (Murdjani et al., 2003).

c. Pengukuran Kualitas Air

Pengukuran kualitas air pada kultur $S$. platensis dilakukan setiap hari. Parameter kualitas air yang diamati meliputi suhu, $\mathrm{pH}$, DO dan salinitas air.

\section{Analisis Data}

Data hasil penelitian disajikan dalam bentuk tabel dan gambar serta dianalisis secara deskriptif yang bertujuan untuk mendeskripsikan gejala yang ada berdasarkan data yang diambil melalui pengamatan atau observasi (Sulipan, 2003).

\section{Hasil dan Pembahasan}

Udang yang terinfeksi dari 5 lokasi di pantai utara Jawa Timur (Situbondo, Probolinggo, Pasuruan, Lamongan dan Tuban) dideteksi dengan menggunakan uji polymerase chain reaction (PCR). Pada tiap-tiap lokasi tersebut dilakukan pengambilan sampel sebanyak 15 ekor dengan jumlah total sampel dari 5 lokasi sebanyak 75 ekor dan diketahui bahwa rata-rata udang yang diperiksa positif IMNV seperti terlihat pada tabel 1, sedangkan grafik persentase jumlah udang terinfeksi dapat dilihat pada gambar 1 . 
Tabel 1. Jumlah Udang Vannamei Yang Terinfeksi dari Beberapa Lokasi

\begin{tabular}{|l|c|c|c|c|c|}
\hline \multirow{2}{*}{ Lokasi } & \multirow{2}{*}{$\begin{array}{c}\text { Positif IMNV } \\
\text { (ekor) }\end{array}$} & \multirow{2}{*}{$\begin{array}{c}\text { Negatif IMNV } \\
\text { (ekor) }\end{array}$} & \multirow{2}{*}{ Jumlah } & \multicolumn{2}{|c|}{ Persentase (\%) } \\
\cline { 4 - 6 } & & 5 & 15 & 67 & $(+)$ \\
\hline Tuban & 10 & 7 & 15 & 53 & 47 \\
Lamongan & 8 & 4 & 15 & 73 & 27 \\
Pasuruan & 11 & 6 & 15 & 60 & 40 \\
Probolinggo & 9 & - & 15 & 100 & - \\
Situbondo & 15 & &
\end{tabular}

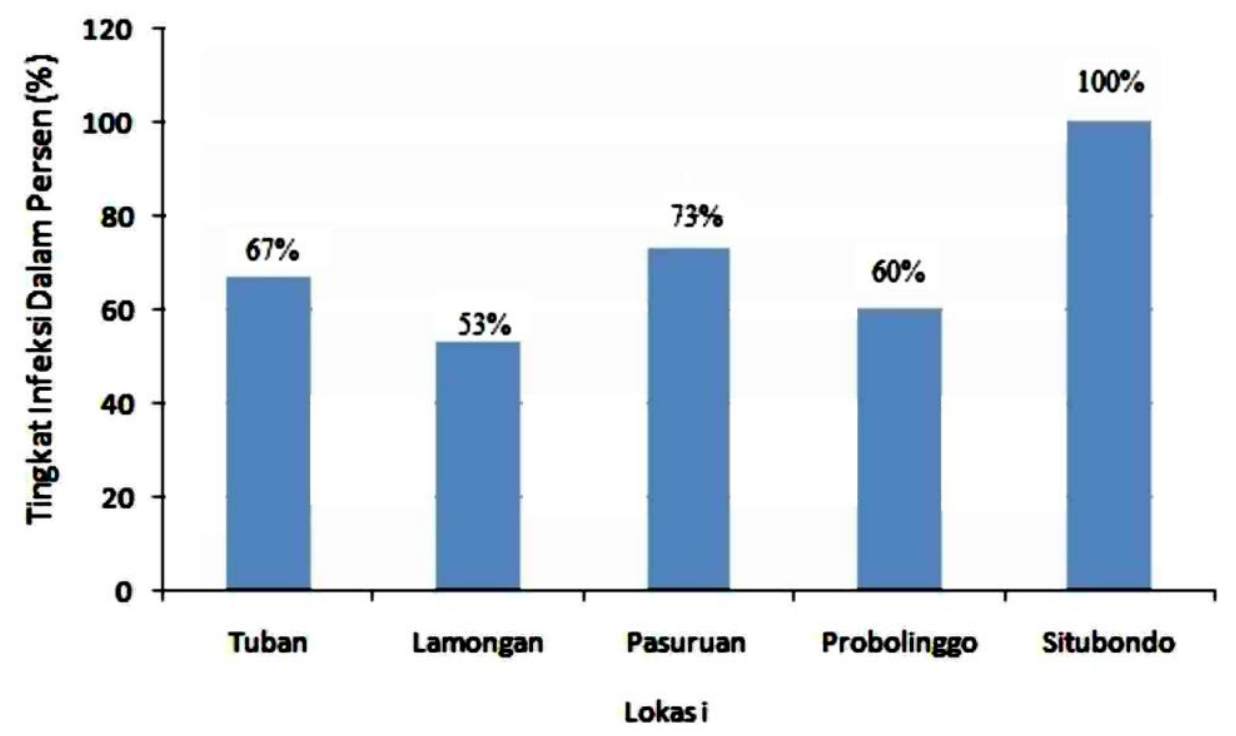

Gambar 1. Grafik persentase udang vannamei yang terinfeksi IMNV

Hasil PCR menunjukkan bahwa daerah Lamongan dari sampel yang diambil sebanyak 15 ekor yang diperiksa, 8 ekor terinfeksi IMNV. Pada daerah Probolinggo jumlah udang yang terinfeksi sebanyak 9 ekor, Tuban 10 ekor, Pasuruan 11 ekor dan Situbondo dengan jumlah udang terinfeksi paling banyak adalah sebanyak 15 ekor.

Grafik persentase jumlah udang vannamei yang terinfeksi IMNV terlihat bahwa persentase sampel yang diperiksa di daerah Lamongan sebesar 53\%, Probolinggo 60\%, Tuban 67\%, Pasuruan $73 \%$ dan Situbondo $100 \%$. Daerah dengan jumlah udang terinfeksi terendah terdapat pada daerah Lamongan, sedangkan daerah dengan jumlah udang terinfeksi tertinggi terdapat pada daerah Situbondo.

Hasil pengukuran kualitas air di 5 lokasi pengambilan sampel dilakukan secara acak. Dari tiap lokasi diambil sampel sebanyak 3 petak tambak yang berdasar pada pengambilan sampel udang. Pengukuran kualitas air masing-masing 3 petak pada tiap lokasi yaitu $\mathrm{pH}$, suhu, oksigen terlarut (Dissolved Oxygen) dan salinitas. $\mathrm{pH}$ dari tiap lokasi berkisar antara 7-8, $\mathrm{pH}$ terendah terdapat pada daerah Lamongan yaitu di petak 2 dan 3 dengan nilai $\mathrm{pH} 7,5$, sedangkan tertinggi pada daerah Situbondo pada petak 3 dengan nilai $\mathrm{pH}$ 7,9 . Suhu selama penelitian berkisar antara $29,3-30,2^{\circ} \mathrm{C}$, suhu terendah terdapat pada daerah Tuban yaitu pada petak 1 dan tertinggi pada daerah Lamongan pada petak 1 dan 3 . Pengukuran DO berkisar 3,8-5,7 ppm dengan DO terendah sebesar 3,8 di daerah Situbondo terdapat pada petak 3 dan tertinggi pada daerah Pasuruan pada petak 1, sedangkan salinitas berkisar antara 9-33 ppt dengan salinitas terendah pada daerah Pasuruan yaitu pada petak 2 dan 3 sebesar 9 ppt dan tertinggi pada daerah Tuban dan Situbondo yaitu sebesar 33 ppt. Kisaran kualitas air dapat dilihat pada tabel 2. 
Tabel 2. Kisaran kualitas air tambak dari 5 lokasi

\begin{tabular}{|l|c|c|c|c|}
\hline \multirow{2}{*}{ Lokasi } & \multicolumn{4}{|c|}{ Kualitas Air } \\
\cline { 2 - 5 } & $\mathrm{pH}$ & $\begin{array}{c}\text { Suhu } \\
\left({ }^{\circ} \mathrm{C}\right)\end{array}$ & $\begin{array}{c}\mathrm{DO} \\
(\mathrm{ppm})\end{array}$ & $\begin{array}{c}\text { Salinitas } \\
(\mathrm{ppt})\end{array}$ \\
\hline Tuban & 7.8 & $29.3-29.5$ & $5.0-5.1$ & 33 \\
Lamongan & $7.5-7.8$ & $29.9-30.2$ & $5.2-5.6$ & $21-23$ \\
Pasuruan & $7.7-7.8$ & $29.4-29.6$ & $4.7-5.7$ & $9-10$ \\
Probolinggo & $7.7-7.8$ & 29.5 & $5.0-5.4$ & $20-21$ \\
Situbondo & $7.7-7.9$ & $29.5-29.6$ & $3.8-5.4$ & $32-33$ \\
\hline
\end{tabular}

Udang yang terserang IMNV mengalami gangguan pada sistem motorik dan nafsu makan berkurang, hal ini sesuai dengan pernyataan Lightner (2003) dan Nuraini et al. (2007) yaitu tanda klinis udang yang terserang IMNV adalah 2 ruas belakang abdomen serta pangkal ekor berwarna putih sampai kemerahan. Karakteristik serangan IMNV secara patologi ditandai dengan adanya nekrosis yang tampak secara kasat mata berwarna putih pada daging udang vannamei dan berlanjut ke warna merah pada bagian ekor kipas dan 2 ruas abdomen terakhir.

Pada penelitian ini, untuk mendeteksi IMNV, digunakan metode PCR. PCR (Polymerase Chain Reaction) adalah satu teknik biokimia dan biologi molekuler untuk memperbanyak DNA secara eksponensial menggunakan enzim replikasi tanpa organisme. PCR adalah metode in vitro pada sintesis asam nukleat dimana segmen DNA tertentu dapat diperbanyak (Saiki, 1990). Berdasarkan hasil uji PCR terhadap udang vannamei di daerah Tuban, Lamongan, Pasuruan, Probolinggo dan Situbondo diperoleh hasil positif terinfeksi IMNV.

Hasil pengamatan dari ke lima lokasi (Tuban, Lamongan, Pasuruan, Probolinggo dan Situbondo), menunjukkan bahwa jumlah udang yang terinfeksi terendah terdapat pada daerah Lamongan sebesar $53 \%$ dan tertinggi pada daerah Situbondo sebesar 100\%, kedua perbedaan tersebut disebabkan karena adanya perbedaan kualitas air pemeliharaan udang vannamei. Dari parameter kualitas air yang diamati, perbedaan salinitas pada daerah Tuban, Pasuruan, dan Situbondo tidak sesuai dengan salinitas budidaya udang vannamei, sedangkan pada daerah Lamongan dan Probolinggo sudah sesuai dengan salinitas optimal untuk budidaya udang vannamei. Host (udang vannamei) akan mampu tumbuh dengan baik apabila dipelihara pada media dengan temperatur $26-30^{\circ} \mathrm{C}$, oksigen terlarut diatas $3 \mathrm{mg} / \mathrm{L}$, $\mathrm{pH}$ 7,5-8,5 dan salinitas 15-30 ppt (Haliman dan Dian, 2006).

Boyd (1982) menjelaskan bahwa efek dari kualitas air yang kurang baik akan lebih besar pengaruhnya untuk udang vannamei disaat sedang mengalami proses ganti kulit (moulting). Kisaran toleransi yang optimal untuk pemeliharaan udang vannamei sebagai media pemeliharaan adalah media bersalinitas 15-30 ppt, hal ini dikarenakan apabila dipelihara pada salinitas yang lebih rendah dari 15 ppt dari kadar garam dari sel tubuh udang, air dari lingkungan akan masuk ke dalam sel tubuh udang melalui membran semipermeabel sel maka kadar garam dalam sel tubuh udang akan menurun, sehingga organ osmoregulator akan mengeluarkan air dari sel tubuh udang, sedangkan pada salinitas yang lebih tinggi dari 30 ppt kadar garam dari dalam sel tubuh udang akan keluar dan air yang berada di lingkungan akan masuk ke dalam sel tubuh udang (Widigdo, 2011).

Perbedaan salinitas berpengaruh terhadap infeksi IMNV pada udang vannamei (Poulos et.al., 2006). Tekanan pada lingkungan dapat mempengaruhi mutasi dari IMNV, setiap tekanan lingkungan pada host akan berpengaruh terhadap genotip sel secara spesifik, faktor lingkungan tersebut meliputi kualitas air yang langsung berhubungan dengan host (Semancik and Duran, 1999 dalam Andalusia, 2011). IMNV bereplikasi di dalam sitoplasma sel otot udang. Udang yang terinfeksi IMNV mengalami respon inflamasi sebagai respon imun yang terjadi pada jaringan terinfeksi, ditandai dengan berkembangnya lesi pada inflamasi jaringan yang di duga sebagai indikasi terjadinya aktivasi respon imunnonspesifik yang disebabkan dsRNA (Robalino et.al., 2004).

Penyebaran IMNV pada tiap daerah dimungkinkan terjadi secara vertikal maupun 
horisontal. Benur yang digunakan oleh petanipetani di daerah tersebut terinfeksi dari induknya, karena tidak adanya sertifikat kesehatan yang menjamin benur tersebut SPF (Spesific Pathogen Free). Benur yang tidak SPF dihasilkan dari indukan yang sudah terinfeksi IMNV dan berada pada lingkungan yang mempunyai biosecurity dengan tingkatan lebih rendah. Benur terserang IMNV karena kontaminasi perairan tambak tanpa treatment dan sterilisasi terlebih dahulu, sehingga air laut yang mungkin terkontaminasi virus dapat menginfeksi benur di perairan tersebut. Fegan and Clifford (2001) menyatakan bahwa penyebaran penyakit di lokasi tambak dapat terjadi dengan beberapa cara antara lain karena udang yang karier, bangkai udang yang mati, kontak dengan objek yang sudah terkontaminasi, sumber air maupun udara yang terkontaminasi. Sistem budidaya pembawa patogen meliputi inang yang terinfeksi (benih, induk, inang vektor dan inang perantara), karier inang biologis (burung, anjing, serangga dan manusia) serta perantara lainnya (air, mobil, sepatu, ember, jaring).

\section{Kesimpulan}

Distribusi Infectious Myo Necrosis Virus (IMNV) di Pantai Utara Jawa Timur meliputi daerah Tuban, Lamongan, Pasuruan, Probolinggo dan Situbondo. Jumlah udang vannamei terinfeksi terendah terdapat pada daerah Lamongan dengan persentase sebesar 53\%, sedangkan pada daerah Probolinggo 60\%, Tuban $67 \%$, Pasuruan $73 \%$ dan tertinggi terdapat pada daerah Situbondo dengan persentase $100 \%$.

Beberapa saran untuk pencegahan distribusi Infectious Myo Necrosis Virus (IMNV) di Pantai Utara Jawa Timur antara lain selalu melakukan kontrol kualitas air yang optimum untuk pertumbuhan udang vannamei, penerapan biosecurity antar tambak, pengawasan kualitas induk dan benih udang vannamei dan monitoring penyakit antara pemerintah, produsen dan konsumen agar mendapatkan informasi tentang penyebaran penyakit IMNV terbaru.

\section{Daftar Pustaka}

Andalusia, R. 2011. Analisis Antigenitas Berdasarkan Susunan Nukleotida, Asam Amino dan Peptida Pada Infectious Myo Necrosis Virus (IMNV) Yang Menyerang Udang Putih (L.vannamei). Disertasi Program Studi S-2 Kedokteran. Fakultas Kedokteran Umum. Universitas Airlangga. 70 hal.
Balai Karantina Ikan Kelas II. 2009. Laporan Pemantauan Hama Dan Penyakit Ikan Karantina. Tanjung Emas. Semarang. 84 hal.

Boyd, CE. 1982. Water Quality Manajement for ponds Fish Culture. Elsevier Scientific Publishing Company, Amsterdam the Netherland. p 7-12.

Dergibson, S. dan Sugiarto. 2002. Metode Statistika Untuk Bisnis dan Ekonomi. Gramedia Pustaka Utama. Jakarta. hal 4-6.

Direktorat Jendral Perikanan dan Kelautan. 2010. http://www.perikanan-budidaya. dkp.go.id . di akses tanggal 12/ 08/ 2010. 5 hal.

Direktorat Jendral Perikanan dan Kelautan. 2010. Buku Saku Pengendalian Penyakit Ikan. Direktur Kesehatan Ikan dan Lingkungan. Jakarta. $127 \mathrm{Hal}$.

Fegan, D. F. and Clifford, H. C. 2001. Health Management For Viral Disease in Shrimp Farms. Procedding of The Special Session On Sustainable Shrimp Farming. World Aquacultue Society. p 168-198

Haliman, R. W. dan Dian A. S. 2006. Udang vannamei. Penebar Swadaya. Jakarta. 48 hal.

Murdjani, M. Nuraini, Y.L. dan Triastutik, G. 2003. Hama Penyakit Ikan dan Udang Pada Usaha Pembenihan. Departemen Kelautan dan Perikanan. Direktorat Jendral Perikanan Budidaya. Balai Budidaya Air Payau Situbondo. Situbonda. 13 hal.

Nuraini, Y.L. 2007. Virus Myo ; Situbondo Diserang Brazil. www.trubusonline.co.id. Malang. Di Akses Tanggal 10/ 03/ 2009.5 hal. 2008. Prevalensi dan Perubahan Histopatologik Infectious Myonecrosis (IMN) Pada Udang Putih (Litopenaeus vannamei) Di Jawa Timur. Program Pasca Sarjana. Fakultas Kedokteran Hewan. Universitas Gajah Mada. Yogyakarta. 66 hal.

Poulos, B.T., K. F. J. Tang, C. R. Pantoja, J. R. Bonami, D. V. Lighner. 2006. Purification and Characterization of Infectious Myonecrosis Virus of Penaeid Shrimp. Journal of General Virologi. 87: 987-996.

Prajitno, A. 2008. Penyakit Ikan-Udang : Virus. UM Press. Malang. 106 Hal. 2008. respository.ipb.ac.id

Robalino, J. Browdy, C. L. Prior, S. Metz, A. Parnell, P. Gross, P. Warr, G. 
2004. Introduction of antiviral immunity by double-stranded RNA in a marine invertebrata. J Virol 78: 10442-10448.

Ruswahono, A. 2011. Pengelolaan Media Budidaya Dalam Upaya Pencegahan Penyakit Pada Pembesaran Udang Vannamei (L.vannamei) Teknologi Intensif Di PT. Segara Indah Kecamatan Besuki. Tulungagung Jawa Timur. www.apsidoarjo.bpsdmkp.kkp. go.id. Tanggal akses 24 September 2011.

Saiki, R. 1990. In PCR Protocols. Academic Press. London. PP. 3-12.

Sulipan. 2003. Penelitian Deskriptif Analisis. www.ktiguru.org. tanggal akses 20 April 2011.

Tang, F.J., Kathy, C.R. Fantoja, B.T. Poulos, R.M. Redman and D.V. Lightner. 2005. In Situ Hybridization Demonstrates That L. vannamei, $L$. styloristris and $P$. monodon Are Susceptible To Experimental Infection With Infectious Myonecrosis Virus (IMNV). Department of Veterinary Science and Microbiology University of Arizona. Arizona. 5 hal.

Tang, F.J., W. F. Ochoa, R.S. Sinkovtsa, B. T. Poulos, S. A. Gabrialc, D. V. Lightner, T. S. Bakera and M. L. Niberte. 2008. Infectious Myonecrosis Virus Has A Totivirus-Like, 120-Subunit Capsid, But With Fiber Complexes at The 